\title{
Curriculum Development Planning in Environmental Education for Developing Environmental Citizenship among Primary School Pupils in Rivers State
}

\author{
Kenneth Kelechi Obasi ${ }^{1}$, Sarah Osah Oyemwen ${ }^{2}$ \\ ${ }^{1}$ Educational Management, Faculty of Education, University of Port Harcourt, Port Harcourt City, Nigeria \\ fxintegritypublishing@gmail.com \\ 2 Department of Educational Management, Faculty of Education, University of Port Harcourt, Port Harcourt, Nigeria
}

\begin{abstract}
This study investigated the level of environmental citizenship development through curriculum development planning among primary school pupils in Rivers State. Three research questions and two hypotheses guided the study. The descriptive survey design was used. The population for the study was the 15,611 teachers in the 962 public primary schools in Rivers State. Stratified random sampling technique was used to draw a sample of 1,600 teachers which represents $10.2 \%$ of the population. A researchers' designed questionnaire titled "Curriculum Development Planning in Environmental Education Questionnaire" was the instruments used for the study. The instruments were validated by three experts. Reliability coefficients of 0.88 (Curriculum Provision), 0.73 (Environmental Education Projects), and 0.79 (Challenges) were derived using Cronbach alpha. Mean and standard deviation were used to answer the research questions while the hypotheses were tested using z-test. Findings revealed that the extent to which environmental education projects were utilized to develop environmental citizenship in pupils is low. The challenges militating against the teaching of environmental education are lack of commitment from the school management, lack of time in the lesson time table to integrate environmental education contents in other subject areas, and teachers' inadequate knowledge of environmental education integration techniques. It was recommended amongst others that the Nigerian Education Research and Development Council should design age-appropriate curriculum contents/topics that can be integrated into various subjects.
\end{abstract}

Keywords: Environmental education, environmental citizenship, curriculum development.

\section{Introduction}

Education is one fundamental and crucial instrument for the improvement of the quality of human life. Quality education ensures the integral development of the individual, taking into cognizance the three basic domains: cognitive, psycho-motor and affective. In this process, the person is developed intellectually, morally, spiritually, physically, socially and psychologically through the acquisition of relevant knowledge, skills and attitudes. It is not surprising therefore that education at the basic level is legally pronounced a right, the denial of which constitutes a crime against the individual. To that extent, United Nations Education, Scientific and Cultural
Organization (2014) unequivocally stated that education is both a human right itself and an indispensable means of realizing other human right. With this in view, the obstacle to achieve Education for All (EFA), must be clearly identified; if they are not, the risk of generating 'false hopes' may in time lead not only observers, but actors to refer retrospectively to what had been an admirable ideology of EFA. The foundation block of this noble project is the primary education.

Primary education is described as the foundation block of formal education. It is the first level of education that provides the basis on which the other levels stand. In some cases, it can be the only education one can have in 
life. One of the goals of primary education is to establish within each child the necessary skills to function throughout his or her academic career and within the community. During primary education, children are introduced to concepts such as cooperation among peers and team spirit. These along with academic basics are structured within the curriculum. According to $\mathrm{McGec}$ (2018), the proper education of the child is a basic tool for effective child upbringing and overall development of the society. Primary education is known for imparting societal norms to children. The extent the school and other social agents do this determine the quality of character or morals the child can exhibit in the larger society. It is important to note that primary school period is an important period in the life of every person. Bloom's taxonomy stated that the rate of intellectual development in people occurs in the following sequence: $0-4$ years $(50 \%, 4-5$ years $(30 \%)$ and 8-17 years $(20 \%)$. Hence, if Bloom's assertion is true, it means that a child who receives a haphazard early child education has lost a huge chunk of his/her intellectual development (Anero, 2014). From the foregoing, quality primary education is the key to human capacity building and national development since it is foundational to the entire process. A process ingredient to guarantee quality primary education delivery is the curriculum.

The curriculum is at the heart of any educational process because it provides meaning and translates concepts, aims, goals, objectives and expectations into concrete reality. It is the substance and the vehicle through which educational goals and objectives are translated into reality. A curriculum is the instructional and educative programme through which pupils achieve their goals, ideals and aspirations in life. Through the curriculum, the general aims of a school education receive concrete expression (Stutt, 2015). Curriculum outlines the skills, performances, attitudes, and values pupils are expected to learn from schooling. It includes statements of desired pupil outcomes, descriptions of materials, and the planned sequence that will be. The success, quality of an education system depends very significantly on the curriculum which refers to the lessons and academic contents taught in a school or in a specific course or programme. It refers to the knowledge and skills students are expected to learn, the units and lessons that teachers teach, the materials, projects, and presentations used in the course; the assignments, tests and methods used to evaluate student learning (The Glossary of Education Reform, 2018). Curriculum development process is therefore required to act as the mirror, reflecting the environmental realities of the time. Curriculum development models can be broken into two broad categories:

i. Product Model: This is result oriented or focused, with the focus more on the finished products, not on the process;

ii. The process model: This is more open-minded and focuses on how learning develops over a period of time (Stutt, 2015).

The curriculum should therefore be reviewed and revised on a regular basis so that it is able to serve the changing needs of both students and society (Physics Catalyst, 2018).

One of those changes that has placed a huge burden on education systems, and by extension the schools, that is exerting devastating effects on the human community and biodiversity is climate change. Climate change, which is also called global warming' is simply described as a significant alteration in the atmospheric composition and condition for a long period of time relative to the sustenance of both human life and biodiversity. The planet earth basically accommodates and sustains human life and the biodiversity. The atmospheric conditions are provided and maintained by nature through the interplay of the atmospheric compositions. In that regard a certain level of temperature is required for life to exist and preserved. According to Onder (20060), the process of interplay of human activities such as the use of fossil fuels, poor land use, industrial applications and home appliance such as refrigerators that use hydrofluorocarbons and chlorofluorocarbons may result in climate change. There are also other human activities that are contributing to global warming such as deforestation that is continuously reducing the number of plant life for the production of oxygen $\left(\mathrm{CO}_{2}\right)$. This is basically the cause of climate change.

Environmental (air, water, land) degradation is the greatest threat to human existence and the biodiversity and the source of this onslaught is multifaceted. Environment pollution occurs when pollutions contaminate the surroundings that lead to changes that affect our normal lifestyles adversely. With modernization and development in the world, pollution has reached its peak, giving rise to global warming and human illness. Pope Benedict xvi in Catholic Secretariat of Nigeria (2011), highlighted how man's aggressive desire to change the earth to suit his own inordinate desires, has turned the world into a theatre of fear, doom and death. He went further to lament that the pollution of the environment is gradually bringing the world to a morbid stage. Environmental pollution occurs in different forms; air, water, soil, radioactive, noise, heat/thermal and light. In some of the world's worst polluted places, babies are born with birth defects, children have lost 30-40 1q points and life expectancy may be as low as 45 years because of cancers and other diseases. The industries all over the world that brought prosperity and affluence, made inroads in the biosphere and disturbed the ecological balances. The improper disposal of industrial waste is a source of soil and water pollution. Household and commercial wastes pollute the environment when not properly deposed (Onder, 2006).

From the foregoing, the fact that the human community and the biodiversity are under unimaginable threat as a result of the unguarded and inordinate activities of man towards the environment is incontrovertibly real. It is a global crisis that requires urgent, aggressive and robust actions to mitigate and one such strategic action is the development of environmental citizenship at the primary education level. Having earlier on identified and 
described primary education as foundational and critical to the integral development of the human person, adopting it as a strategic platform for the development of environmental citizenship is very appealing. This position is reinforced by the axiom "catch them young" which is the expression of the intention to start early to develop in the child positive capacities and willingness to become great assets to themselves and the society at large. The concept of 'environmental citizenship' is better understood and appreciated when disaggregated. Citizenship denotes that a person is a legal member of a political community, state or nation with rights, obligations and responsibilities. The word environment' means all the physical surroundings on earth that encompasses all living and non-living things. Human beings, animals, plants and all other living things rely on the non-living parts of the environment to survive.

Environmental citizenship therefore implies one's legal membership to the earth's environmental community with the corresponding rights, obligations and responsibilities. Almost every human activity is related to the environment in one way or the other and the environment is by natural design, the common heritage of the human family. An environmental citizen is committed to learning more about the environment and to taking responsible environmental actions. Through a combination of interactive activities assignments and discussions, students learn how they are personally connected with current environmental issues. They are also encouraged to adopt attitudes and behaviours that forester global environmental responsibility. Environmental citizenship develops in individuals and groups the capacity to relate positively and in a friendly manner towards the environment. It builds in them the culture of respect, care and protection of the environment as a commonwealth with dignity. The key change from an unsustainable to sustainable approach towards the environment and various human activities lies in education. Hence, it is not a question of whether environmental citizenship should be included in the education curricula, but it should be implemented in all levels of education as soon as possible. As submitted by Morgado et al (2020), another way of strengthening environmental citizenship is participation in volunteering initiatives, which may be considered as a potential tool for shaping the attitude of improving community character and cohesion.

Environmental Education (EE) is a comprehensive learning process that develops in individuals the capacity to behave responsibly towards the environment and the skills and competencies for solving environmental issues holistically. It is a lifelong learning process directed at creating responsible individuals who explore and identify environmental issues, engage in problem solving and take action effectively to improve the environment. It provides opportunities for children to build skills to become environmentally-smart, including problem-solving and investigative skills to help mitigate the environmental problems. The main objectives of EE therefore include fostering clear awareness of, and concern about economic, social, political and ecological interdependence in urban and rural areas, to provide every person with opportunities to acquire the knowledge, values, attitudes, commitment and skills needed to protect and improve the environment. It helps to create new patterns of behaviour of individuals, groups and society as a whole towards the environment (IIEP, 2006). With EE, individuals are grown, that are sensitive, conscious and tender about environmental issues and students get sufficient environmental education that can enhance their consciousness about environmental problems. Environmental education is therefore an essential tool for training students and individuals to live in a sustainable society. Young generations are basically the most important target group for environmental education, and in this study, primary school pupils are the target group.

\section{Statement of the Problem}

From the close of the $20^{\text {th }}$ century to this $21^{\text {st }}$ century and with the $19^{\text {th }}$ century industrial revolution as the launching pad, the world has been aggressively revolutionized, particularly in the areas of science and technology. There is still more scientific and technological breakthroughs. These have brought a lot of prosperity to humanity, but very sadly, at a very high cost to humanity and the biodiversity, which is gradually bringing the world to a morbid stage. The greatest causality of all these is the environment, with the inhabitants (living and non-living things) as the victims. The generation behind is characterized by unbridled, inordinate and consumerist lifestyle that has turned the world into a theatre of fear, doom and death. All the component parts of the environment are grossly polluted, the ecosystems are dangerously degraded by the unwholesome activities of man with devastating consequences such as extreme weather conditions; storms, earthquakes, severe hurricanes, volcanoes, acid rains, spread of deadly diseases, the deaths of humans, animals, aquatic lives and endangered ecosystems that are impacting negatively on agriculture and food supply thereby increasing hunger and poverty especially in the developing world. In the face of the monster, is there anything that could be done to mitigate the situation? Can the education system raise a generation with a better and more positive mind-set and lifestyle to alter the status quo?

\section{Aim and objectives of the study}

The aim of the study was to determine the level of environmental citizenship development through curriculum development planning among primary school pupils in Rivers State. Specifically the objectives of the study were to determine the following:

- The curriculum provisions in environmental education for developing environmental citizenship among primary school pupils in Rivers State.

- The extent to which environmental education projects are utilized to develop environmental 
citizenship among primary school pupils in Rivers State.

- $\quad$ The challenges militating against the teaching of environmental education in order to develop environmental citizenship among primary school pupils in Rivers State.

\section{Research Questions}

- What are the curriculum provisions in environmental education for developing environmental citizenship among primary school pupils in Rivers State?

- What is the extent to which environmental education projects are utilized to develop environmental citizenship among primary school pupils in Rivers State?

- What are the challenges militating against the teaching of environmental education in order to develop environmental citizenship among primary school pupils in Rivers State?

\section{Hypotheses}

- There is no significance difference between the mean scores of teachers in urban and rural schools with respect to the extent environmental education projects were utilized to develop environmental citizenship among primary school pupils in Rivers State.

- There is no significance difference between the mean scores of teachers in urban and rural schools with respect to the challenges militating against the teaching of environmental education in order to develop environmental citizenship among primary school pupils in Rivers State.

\section{Methodology}

The research design used for this study was the descriptive survey design. The population for the study was the 15,611 teachers in the 962 public primary schools in Rivers State. (Source: Statistics Department of the Rivers State Universal Basic Education Board, 2021). A sample of 1,600 teachers which represents $10.2 \%$ of the population was used for the study. The sample was made up of 698 teachers in urban schools and 902 teachers in rural schools. Stratified random sampling was used to draw the sample for the study. The 23 local government areas in the state were stratified into upland and riverine area. 10 local government areas were randomly drawn from the groups and 8 schools were randomly selected from each Local Government Areas. From each school, 20 teachers were randomly selected and a total of 1,600 teachers were used for the study. A researcher's designed questionnaire titled: "Curriculum Development Planning in Environmental Education Questionnaire" (CDPEEQ) was used for the study. The CDPEEQ had 2 sections. Section A dealt with demographic information. Section B had 19 items. It was divided into 3 parts. The response pattern for the items was structured on a four (4) point Liket type scale of Strongly Agree (SA), Agreed (A),
Disagree (D) and Strongly Disagree (SD) with values 4, 3 , 2 and 1 respectively. Cronbach Alpha technique was used to establish the reliability. The following reliability coefficients were obtained for the 3 parts of the CDPEEQ; Curriculum Provision: 0.88, Environmental Education Projects: 0.73, Challenges: 0.79 and the entire instrument: 0.78. Mean and standard deviation was used to answer the research question while z-test was used to test the null hypothesis at a probability level of 0.05 .

\section{Results}

Research Question 1: What are the curriculum provisions in environmental education for developing environmental citizenship among primary school pupils in Rivers State?

Table ( 1) Frequency and Percentage of Respondents Opinions on the Curriculum Provisions in Environmental Education for Developing Environmental Citizenship among Primary School Pupils in Rivers State

\begin{tabular}{|c|l|l|l|l|}
\hline S & $\begin{array}{l}\text { Questionnaire } \\
\text { Percenta } \\
\text { ge (\%) } \\
\text { Yes }\end{array}$ & No & $\begin{array}{l}\text { Remark } \\
\text { s }\end{array}$ \\
\hline 1 & $\begin{array}{l}\text { Does your school curriculum } \\
\text { have environmental education } \\
\text { contents that are integrated } \\
\text { into other subject areas? }\end{array}$ & 57.9 & 42.1 & High \\
\hline 2 & $\begin{array}{l}\text { Does your school organize its } \\
\text { environmental education } \\
\text { curriculum around significant } \\
\text { environmental issues and } \\
\text { problems in the locality? }\end{array}$ & 23.25 & 76.75 & Low \\
\hline 4 & $\begin{array}{l}\text { Are the contents of your } \\
\text { school's environmental } \\
\text { education curriculum directed } \\
\text { towards developing learners' } \\
\text { awareness of the need for } \\
\text { them to be responsible } \\
\text { environmental citizens? }\end{array}$ & 38.25 & 61.75 & Low \\
\hline 5 & $\begin{array}{l}\text { Are there appropriately } \\
\text { designed learning experiences } \\
\text { and activities for the learners } \\
\text { at every instructional } \\
\text { encounter in your school's } \\
\text { environmental education } \\
\text { curriculum? }\end{array}$ & $\begin{array}{l}\text { Does the instructional delivery } \\
\text { process of your school's } \\
\text { environmental education } \\
\text { curriculum motivate learners } \\
\text { to become good } \\
\text { environmental citizens? }\end{array}$ & 56.8 & Low \\
\hline 7 & $\begin{array}{l}\text { Are there adequate } \\
\text { instructional materials on } \\
\text { environmental education in } \\
\text { your school? }\end{array}$ & 73.2 & High \\
\hline
\end{tabular}

In table (1), 57.9\% agreed that their school curriculum have environmental education contents that are integrated into other subject areas, while $56.8 \%$ agreed that the instructional delivery process of their school's environmental education curriculum motivate learners to become good environmental citizens. However, 38.25\% of the respondents agreed that the contents of their school's environmental education curriculum is directed towards developing learners' awareness of the need for them to be responsible environmental citizens, $23.25 \%$ of respondents agreed that there school organize its 
environmental education curriculum around significant environmental issues and problems in the locality, $12.6 \%$ agreed that there are appropriately designed learning experiences and activities for the learners at every instructional encounter in your school's environmental education curriculum, while $7 \%$ agreed that there are adequate instructional materials on environmental education in their school.

Research Question 2: What is the extent to which environmental education projects are utilized to develop environmental citizenship among primary school pupils in Rivers State?

Table (2)Mean (X), Standard Deviation, Mean Set and Rank Order of Respondents Opinions on the Extent to which Environmental Education Projects were Utilized to Develop Environmental Citizenship among Primary School Pupils in Rivers State

\begin{tabular}{|c|c|c|c|c|c|c|c|c|}
\hline \multirow[t]{2}{*}{$\begin{array}{l}\mathrm{S} / \\
\mathrm{N}\end{array}$} & \multirow[t]{2}{*}{ Questionnaire } & \multicolumn{2}{|c|}{$\begin{array}{l}\text { Urban Schools } \\
\text { Teachers } \\
N_{1}=698\end{array}$} & \multicolumn{2}{|c|}{$\begin{array}{l}\text { Rural } \\
\text { School } \\
\text { Teachers } \\
\mathrm{N}_{2}=\quad 902 \\
\end{array}$} & \multirow{2}{*}{$\begin{array}{c}\begin{array}{c}\text { Mean } \\
\text { Set }\end{array} \\
\left(X_{1}\right) \\
\left(X_{2}\right) \\
\end{array}$} & \multirow[t]{2}{*}{$\begin{array}{l}\text { Rank } \\
\text { Rema } \\
\text { rks } \\
\text { Order }\end{array}$} & \multirow[t]{2}{*}{ Remark } \\
\hline & & $X_{1}$ & $\begin{array}{c}\text { Sd } \\
1\end{array}$ & $X_{2}$ & $\mathrm{Sd}_{2}$ & & & \\
\hline 7 & $\begin{array}{l}\text { Environmental } \\
\text { Exhibitions }\end{array}$ & 3.00 & 0.77 & $\begin{array}{c}2.6 \\
8\end{array}$ & 0.68 & 2.84 & $\begin{array}{l}3^{\text {rd }} \\
\text { High } \\
\text { Extent }\end{array}$ & Disagreed \\
\hline 8 & $\begin{array}{l}\text { Commemoration Of } \\
\text { World Environment Day }\end{array}$ & 1.50 & 0.67 & $\begin{array}{c}1.4 \\
7\end{array}$ & 0.65 & 1.49 & $\begin{array}{l}7^{\text {th }} \\
\text { Low } \\
\text { Extent }\end{array}$ & Agreed \\
\hline 9 & $\begin{array}{l}\text { Participating In Cleaning } \\
\text { Campaigns In The } \\
\text { School's Outdoor } \\
\text { Spaces }\end{array}$ & 2.70 & 0.46 & $\begin{array}{c}3.3 \\
5\end{array}$ & 0.59 & 3.03 & $\begin{array}{l}2^{\text {nd }} \\
\text { High } \\
\text { Extent }\end{array}$ & Disagreed \\
\hline 10 & $\begin{array}{l}\text { Invitation Of } \\
\text { Environmental } \\
\text { Management Personnel } \\
\text { To Enlighten Pupils On } \\
\text { Environmental Issues }\end{array}$ & 2.70 & 0.46 & $\begin{array}{c}2.2 \\
0\end{array}$ & 0.60 & 2.45 & $\begin{array}{l}4^{\text {th }} \\
\text { Low } \\
\text { Extent }\end{array}$ & Disagreed \\
\hline 11 & $\begin{array}{lr}\text { Participation } & \text { In } \\
\text { Environmental } & \text { Club } \\
\text { Activities } & \\
\end{array}$ & 2.70 & 0.64 & $\begin{array}{c}3.4 \\
0\end{array}$ & 0.49 & 3.05 & $\begin{array}{l}\text { st } \\
\text { High } \\
\text { Extent }\end{array}$ & Disagreed \\
\hline $\begin{array}{l}12 \\
13\end{array}$ & $\begin{array}{lrr}\text { Students Visit } & \text { To } \\
\text { Natural Habitats } & \text { And } \\
\text { Flora Environments }\end{array}$ & 2.00 & 0.60 & $\begin{array}{c}2.5 \\
0\end{array}$ & 0.50 & 2.25 & $\begin{array}{l}5^{\text {th }} \\
\text { Low } \\
\text { Extent }\end{array}$ & Agreed \\
\hline & $\begin{array}{l}\text { Planting Of Native } \\
\text { Species Of Trees And } \\
\text { Flowers In And Around } \\
\text { The School Premises }\end{array}$ & 1.30 & 0.46 & $\begin{array}{c}2.4 \\
0\end{array}$ & 0.49 & 1.85 & $\begin{array}{l}6^{\text {th }} \\
\text { Low } \\
\text { Extent }\end{array}$ & Agreed \\
\hline & Aggregate & 2.27 & 0.58 & $\begin{array}{c}2.5 \\
7 \\
\end{array}$ & 0.57 & 2.42 & $\begin{array}{l}\text { Low } \\
\text { Extent }\end{array}$ & Disagreed \\
\hline
\end{tabular}

In table ( 2) respondents agreed that the extent to which the following environmental education projects were utilized to develop environmental citizenship in pupils is high: participation in environmental club activities, participating in cleaning campaigns in the school's outdoor spaces and environmental exhibitions. These items had mean scores of 3.05, 3.03 and 2.84 respectively which are above the criterion mean of 2.50 . Respondents agreed that the extent to which the following environmental education projects were utilized to develop environmental citizenship in pupils is low: invitation of environmental management personnel to enlighten pupils on environmental issues, and visit to natural habitats and flora environments, planting of native species of trees and flowers in and around the school premises is not essential in helping students to become good environmental citizens and commemoration of World Environment Day with respective mean scores of $2.45,2.25,1.85$ and 1.49 below the criterion mean of 2.50. The aggregate mean of 2.42 further showed that the extent to which environmental education projects were utilized to develop environmental citizenship in pupils is low.

Research Question 3: What are the challenges militating against the teaching of environmental education in order to develop environmental citizenship among primary school pupils in Rivers State?

Table( 3)Mean (X), Standard Deviation, Mean Set and Rank Order of Respondents Opinions on the Challenges Militating Against the Teaching of Environmental Education in order to Develop Environmental Citizenship among Primary School Pupils in Rivers State

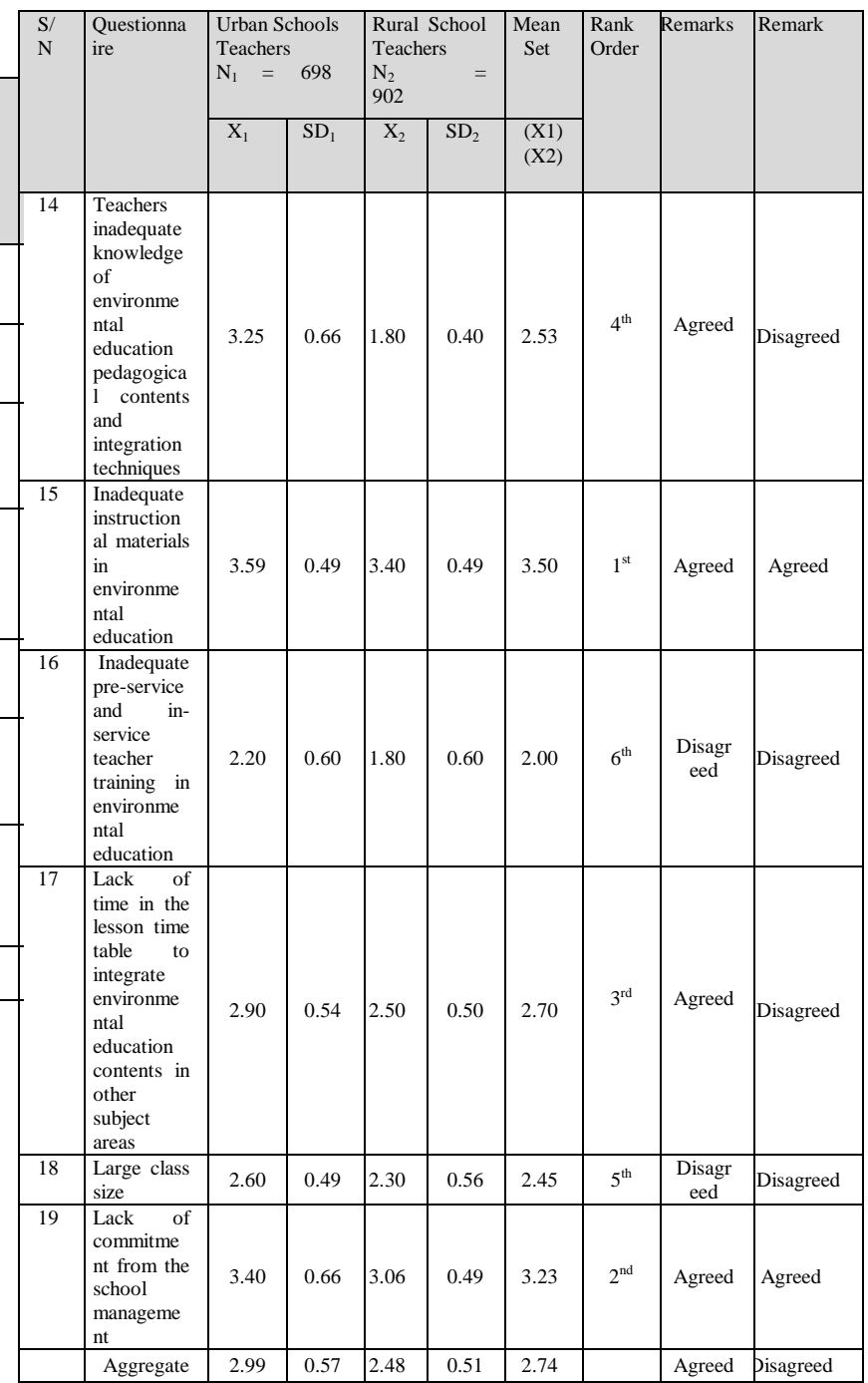

In Table(3) respondents agreed that the following are challenges militating against the teaching of environmental education in Rivers State: inadequate instructional materials, lack of commitment from the school management, lack of time in the lesson time table to integrate environmental education contents in other subject areas, and teachers inadequate knowledge of 
environmental education pedagogical contents and integration techniques. These items had mean scores of $3.50,3.23,2.70$, and 2.53 respectively which are above the criterion mean of 2.50. Respondents disagreed that the following are challenges militating against the teaching of environmental education in Rivers State: large class size and inadequate pre-service and in-service teacher training in environmental education with respective mean scores of 2.45 and 2.00 below the criterion mean of 2.50 . The aggregate mean of 2.74 further showed that these are the challenges militating against the teaching of environmental education in Rivers State.

$\mathbf{H O}_{1}$ : There is no significance difference between the mean scores of teachers in urban and rural schools with respect to the extent environmental education projects were utilized to develop environmental citizenship among primary school pupils in Rivers State

Table (4) Z-Test Analysis of Difference between the Mean Scores of Teachers in Urban and Rural Schools with Respect to the Extent Environmental Education Projects Were Utilized to Develop Environmental Citizenship among Primary School Pupils in Rivers State

\begin{tabular}{|c|c|c|c|c|c|c|c|}
\hline Respondents & $\mathbf{N}$ & $\mathbf{x}$ & SD & Df & Z-cal & $\begin{array}{l}\text { Z- } \\
\text { critical }\end{array}$ & Decision \\
\hline $\begin{array}{l}\text { Urban } \\
\text { Schools } \\
\text { Teachers }\end{array}$ & 698 & 2.27 & 0.58 & \multirow{2}{*}{1598} & \multirow{2}{*}{-10.34} & \multirow{2}{*}{ \pm 1.96} & \multirow{2}{*}{$\begin{array}{c}\mathbf{H}_{\mathbf{0 1}} \\
\text { was } \\
\text { rejected }\end{array}$} \\
\hline $\begin{array}{l}\text { Rural } \\
\text { Schools } \\
\text { Teachers }\end{array}$ & 902 & 2.57 & 0.57 & & & & \\
\hline Total & 1600 & & & & & & \\
\hline
\end{tabular}

Table (4) showed that the $\mathrm{z}$-test calculated is -10.34 which is greater than the $\mathrm{z}$-critical value of \pm 1.96 at 1598 degree of freedom and at 0.05 alpha level. Since the $\mathrm{z}$-calculated is greater than the $\mathrm{z}$-critical the null hypothesis was rejected and the alternate hypothesis was accepted.

$\mathbf{H O}_{2}$ : There is no significance difference between the mean scores of teachers in urban and rural schools with respect to the challenges militating against the teaching of environmental education in order to develop environmental citizenship among primary school pupils in Rivers State.

Table (5)Z-Test Analysis of Difference between the Mean Scores of Teachers in Urban and Rural Schools with Respect to the Challenges Militating against the Teaching of Environmental Education in order to Develop Environmental Citizenship among Primary School Pupils in Rivers State

\begin{tabular}{|c|c|c|c|c|c|c|c|}
\hline Respondents & $\mathbf{N}$ & $\mathbf{X}$ & SD & Df & Z-Cal & Z-Critical & Decision \\
\hline $\begin{array}{l}\text { Urban } \\
\text { Schools } \\
\text { Teachers }\end{array}$ & 698 & 2.99 & 0.57 & \multirow[t]{2}{*}{1598} & \multirow[t]{2}{*}{18.58} & \multirow[t]{2}{*}{ \pm 1.96} & \multirow{2}{*}{$\begin{array}{c}\mathbf{H}_{\mathbf{0 2}} \\
\text { was } \\
\text { rejected }\end{array}$} \\
\hline $\begin{array}{l}\text { Rural Schools } \\
\text { Teachers }\end{array}$ & 902 & 2.48 & 0.51 & & & & \\
\hline Total & 1600 & & & & & & \\
\hline
\end{tabular}


the teaching of English language. To effectively develop environmental citizenship among pupils, it is necessary to combine the various methods of teaching EE so that they can complement each other. Also, the finding showed that there is a significance difference between the mean scores of teachers in urban and rural schools with respect to the extent environmental education projects were utilized to develop environmental citizenship among primary school pupils in Rivers State. A possible reason for this difference in opinion could be more exposure and awareness of environmental issues on the part of the teachers in urban areas.

Finding of the study also revealed the challenges militating against the teaching of environmental education in Rivers State. These are inadequate instructional materials, lack of commitment from the school management, lack of time in the lesson time table to integrate environmental education contents in other subject areas, and teachers' inadequate knowledge of environmental education pedagogical contents and integration techniques. This finding is in tandem with the work of Jekayinfa and Yusuf (2020). They conducted a study on the level of teachers' incorporation of environmental education concepts in the Nigerian primary school curriculum and the result showed that teachers had no time on the timetable to integrate environmental education into other subjects in accordance with student needs. Correspondingly, Aiyedun and Ogunode (2021) study on shortage of professional environmental education teachers in Nigeria revealed that there is a scarcity of environmental education experts, teaching manuals and a congestion of the current school time-table was has strong negative implications for the implementation of EE within the school system. Respondents agree that inadequate provision of instructional materials is a challenge militating against the teaching of environmental education. Nevertheless, the issue of inadequate provision of instructional materials to support environmental education should not be a challenge. Sukma et al (2020) submitted that textbooks from different subjects now include chapters on environmental topics and learning materials about environmental education can be found in various kinds of media. Furthermore, teachers can use the internet, where available, to find environment related resources that can be adapted to meet their students needs. Also, finding from this study showed that there is a significance difference between the mean scores of teachers in urban and rural schools with respect to the challenges militating against the teaching of environmental education in order to develop environmental citizenship among primary school pupils in Rivers State. This is because location and exposure probably exerted influence on the respondents' awareness and knowledge about environmental education.

\section{Conclusions}

It was concluded that the level of developing environmental citizenship through curriculum development planning in environmental education is low.
However, EE is exceedingly important, because it awareness influences our actions and give us the opportunity to take ownership of our natural environment.

\section{Recommendation}

Based on the findings, the following recommendations were made:

1) Since EE is integrated into other subjects, the Nigerian Education Research and Development Council should design age-appropriate curriculum contents/topics that can be integrated into various subjects to ensure uniformity of contents taught instead of leaving every school to develop their own topics that may not be age and developmentally appropriate enough to motivate the pupils to become responsible environmental citizens..

2) Head Teachers should organize their EE curriculum around significant environmental issues and problems in their locality and they should monitor teachers to ensure that their teaching techniques and methods are directed towards developing learners' awareness of the need for them to be responsible environmental citizens.

3) In service teachers should be given on the job training through organized workshops and seminars where they will be exposed to better and more effective ways of EE lesson integration. Also $\mathrm{EE}$ contents and integration techniques should be included in pre-service teacher curriculum to enhance their knowledge base.

4) Head teachers should plan the lesson timetable so that sufficient time is allocated to subjects that have high capacity to integrate $\mathrm{EE}$ topics like science and civic education.

\section{References}

[1] Aiyedun, O. \& Ogunode, N. J. (2021). Shortage of professional science and environmental education teachers in Nigeria. Asian Journal of Science Education, 3(1), 1-11.

[2] Anero, N. (2014). Relevance and challenges of primary education to the overall development of the child and the Nigerian society. Global Journal of Educational Research. 14, 55-62.

[3] Catholic Secretariat of Nigeria (2011). Sustaining our environment for integral human development. Lagos Catholic Secretariat of Nigeria.

[4] Chuku, E. N. (2020). Combining language learning with environmental awareness in Nigeria by using content based instruction strategy. Academia Arena, 12(2), 1-8.

[5] Egbezor, D. E. \& Brisk-Elemele, C. (2016). The influence of environmental education on the behaviour of senior secondary school students in Port Harcourt, Nigeria. International Journal of Education and Evaluation, 2(2), 51-65.

[6] Federal Republic of Nigeria (2014). National policy on education $\left(6^{\text {th }} \mathrm{ed}\right)$. NERDC Press.

[7] Ibitoye, P. \& Ilesanmi, O. S. (2019). Opinion of environmental education students on teaching 
methods in higher education: a descriptive research. International Journal of Educational Excellence, 5(2), 65-74.

[8] International Institute for Educational Planning (2006). Environmental education. UNESCO

[9] Jekayinfa, A. A. \& Yusuf, A. R. (2020). Teachers' opinions on the incorporation of environmental education in the Nigerian primary school curriculum. International Journal of Education Research and Reviews, 8(8), 1-5.

[10] McGee, K (2018). Definition of primary education.https://www.theclassroom.com/definiti on-primary-education-5076822.html

[11] Morgado, I., Dordevic, S., Gasparovic, Z., Radovic, S. \& Keranova, D. (2020). Conceptualizing environmental citizenship for $21^{\text {st }}$ century education. Societal Issues and Environmental Citizenship, 4, 49-66.

[12] Oluwatade, O. O. \& Gana, C. S. (2019). Integration of environmental education into secondary physics curriculum for sustainable development in Nigeria. International Journal of African Sustainable Development, 10(2), 305312.

[13] Onder, S. (2006). Environmental pollution and solution recommendations of Konya City, Turkey. Journal of Applied Science 6, 864-871.

[14] Onwuemele, A. (2018). Achieving sustainable development goals (SDGs) through environmental education in Nigeria. International Journal of Research in Environmental Studies, 5, 48-55.

[15] Physics Catalyst (2018). Curriculum Development, Need and Importance. https://physicscatalyst.com/graduation/curriculu m-development-need-importance/

[16] Stutt, A. (2015). Curriculum development the 3 models explained. https://tophat.com/blog/curriculum-developmentmodels-design/

[17] Sukma, E., Ramadhan, S., \& Indriyani, V. (2020). Integration of environmental education in elementary schools. IOP Conference Series: Journal of Physics, 315, 12-21.

[18] The Glossary of Education Reform (2015). Curriculum.

https://www.edglossary.org/curriculum/

[19] United Nations Educational Scientific and Cultural Organization (2014). Right to education: Scope and implementation. UNESCO.

[20] United Nations Educational Scientific and Cultural Organization (2019). Climate change education. UNESCO.et mobilité au Mali. Langaa RPCIG. 